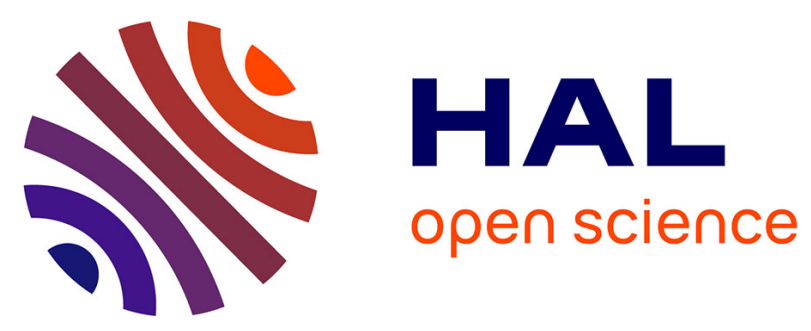

\title{
Temperature Effects on the Unsaturated Permeability of the Densely Compacted GMZ01 Bentonite under Confined Conditions
}

\author{
Wei-Min Ye, Min Wan, Bao Chen, Yong-Gui Chen, Yu-Jun Cui, Ju Wang
}

\section{To cite this version:}

Wei-Min Ye, Min Wan, Bao Chen, Yong-Gui Chen, Yu-Jun Cui, et al.. Temperature Effects on the Unsaturated Permeability of the Densely Compacted GMZ01 Bentonite under Confined Conditions. Engineering Geology, 2012, 126, pp.1-7. 10.1016/j.enggeo.2011.10.011 . hal-00693404

HAL Id: hal-00693404

https://hal-enpc.archives-ouvertes.fr/hal-00693404

Submitted on 2 May 2012

HAL is a multi-disciplinary open access archive for the deposit and dissemination of scientific research documents, whether they are published or not. The documents may come from teaching and research institutions in France or abroad, or from public or private research centers.
L'archive ouverte pluridisciplinaire HAL, est destinée au dépôt et à la diffusion de documents scientifiques de niveau recherche, publiés ou non, émanant des établissements d'enseignement et de recherche français ou étrangers, des laboratoires publics ou privés. 
5 a. Key Laboratory of Geotechnical and Underground Engineering of Ministry of Education, Tongji

6 University, Shanghai 200092 , China

7 b. United Research Center for Urban Environment and Sustainable Development, the Ministry of

8 Education, Shanghai 200092 , China

9 c. UR Navier, Ecole des Ponts ParisTech, France

10 d. Beijing Research Institute of Uranium Geology, Beijing 100029, China

12 *To whom correspondence and reprint requests should be addressed; Tel.: +86 216598 3729; Fax: $13+86216598$ 2384, E-mail: ye_tju@tongji.edu.cn 
15 Abstract

In this study, temperature controlled soil-water retention tests and unsaturated hydraulic conductivity tests for densely compacted Gaomiaozi bentonite - GMZ01 (dry density of $1.70 \mathrm{Mg} / \mathrm{m}^{3}$ ) were performed under confined conditions. Relevant soil-water retention curves (SWRCs) and unsaturated hydraulic conductivities of GMZ01 at temperatures of $40^{\circ} \mathrm{C}$ and $60^{\circ} \mathrm{C}$ were obtained. Based on these results as well as the previously obtained results at $20^{\circ} \mathrm{C}$, the influence of temperature on water-retention properties and unsaturated hydraulic conductivity of the densely compacted Gaomiaozi bentonite were investigated. It was observed that: (i) water retention capacity decreases as temperature increases, and the influence of temperature depends on suction; (ii) for all the temperatures tested, the unsaturated hydraulic conductivity decreases slightly in the initial stage of hydration; the value of the hydraulic conductivity becomes constant as hydration progresses and finally, the permeability increases rapidly with suction decreases as saturation is approached; (iii) under confined conditions, the hydraulic conductivity increases as temperature increases, at a decreasing rate with temperature rise. It was also observed that the influence of temperature on the hydraulic conductivity is quite suction-dependent. At high suctions ( $>$ > $60 \mathrm{MPa}$ ), the temperature effect is mainly due to its influence on water viscosity; by contrast, in the range of low suctions (s < $60 \mathrm{MPa}$ ), the temperature effect is related to both the water viscosity and the macro-pores closing phenomenon that is supposed to be temperature dependent.

Key words : GMZ bentonite; nuclear waste repository; temperature; water-retention property; unsaturated permeability 


\section{Introduction}

In a conceptual multi-barrier disposal radioactive waste repository (Figure 1), significant Temperature- Hydraulic-Mechanical (THM) phenomena take place in the engineered barrier and in the near field due to the combined actions of heating and hydration (Sanchez et al, 2004). The hydraulic property of the compacted bentonite used as engineered barrier material is one of the key properties for the design of such a disposal system. This explains the large number of studies that have been performed in this area: Dixon et al (1987), Nachabe (1995) and Liu and Wen (2003) tested the permeability of saturated compacted bentonites and analyzed the related influencing factors; Villar $(2000,2002)$ and Komine (2004) reported different empirical relations between dry density and saturated permeability of compacted benonite; Komine (2004) and He and Shi (2007) predicted the saturated permeability of bentonite based on the changes in porosity. For the unsaturated bentonite, after an investigation to the unsaturated permeability of the mixture of the Kunigel V1 bentonite and Hostun sand under confined conditions, Loiseau (2001) found that for suction lower than 23MPa, the unsaturated permeability increases with suction decrease, while for suction higher than $23 \mathrm{MPa}$, the unsaturated permeability decreases as suction decreases. Under both confined conditions and unconfined conditions, Cui et al. (2008) tested the unsaturated permeability of the mixture of Kunigel-V1 bentonite/Hostun sand based on the instantaneous profile method, and found that as suction decreases, the unsaturated permeability decreases to a certain value and then turns to increase.

Cho et al. (1999) reported that the influence of temperature on the permeability of bentonite is mainly because the intrinsic permeability, viscosity and density of water are influenced by temperature. Changes in viscosity of water with temperature have been found to be the most important mechanism (Towhata et al, 1993; Cho et al, 2000; and Villar and Lloret, 2004).

GMZ bentonite has been selected as the potential buffer/backfill material for the construction of the engineered barrier in the Chinese deep geological disposal program for high level radioactive nuclear waste, thanks to its high montmorillonite content, high cation exchange capacity (CEC), large specific surface and other desirable properties (Liu and Wen, 2003). Studies on the mineralogy and chemical composition, mechanical properties, hydraulic behavior, swelling behavior, thermal conductivity, microstructure and volume change behavior of the GMZ bentonite have been conducted over years (Ye et al., 2010b). The investigation of the hydraulic properties of the GMZ bentonite has been the gravity center of the recent studies. Liu and Wen (2003) tested the saturated permeability and analyzed the related influencing factors of the compacted GMZ bentonite. Using the instantaneous profile method, Ye et al. (2010a) tested the unsaturated permeability of the densely compacted specimen, with a dry density of $1.7 \mathrm{Mg} / \mathrm{m}^{3}$, under confined (constant-volume) conditions. Results show that the unsaturated hydraulic conductivity of the compacted bentonite changes from $1.13 \times 10^{-13}$ $\mathrm{m} / \mathrm{s}$ to $8.41 \times 10^{-15} \mathrm{~m} / \mathrm{s}$ (gravimetric water content from $12 \%$ to $28 \%$ ) and it is not solely function of suction. While under unconfined (free-swelling) conditions, the unsaturated hydraulic conductivity of the Gaomiaozi bentonite is in a larger range of $1.0 \times 10^{-12}-1.0 \times 10^{-15} \mathrm{~m} / \mathrm{s}$. Based on the Kozeny-Carmen semi-empirical function, Niu et al (2009) proposed a semi-empirical equation for the calculation of the unsaturated permeability of the GMZ bentonite with the consideration of micro-structural changes.

As far as the influence of temperature effect is concerned, Ye et al. (2009b) reported that the water retention capacity of the highly-compacted GMZ bentonite and bentonite-based mixtures decreases as the temperature increases, regardless of the confining conditions.

In this paper, the soil-water retention curves (SWRCs) of the densely compacted Gaomiaozi 
bentonite (GMZ01) under confined conditions and at various temperatures $\left(20^{\circ} \mathrm{C}, 40^{\circ} \mathrm{C}\right.$ and $\left.60^{\circ} \mathrm{C}\right)$ are presented. Based on the results obtained, the unsaturated permeability of the GMZ01 is investigated by performing infiltration tests under controlled temperature.

\section{Materials}

The Gaomiaozi deposit is located in the northern Chinese Inner Mongolia autonomous region, $300 \mathrm{~km}$ northwest from Beijing (Ye et al., 2009a, 2010b). Some basic properties of the GMZ01 bentonite tested in this paper are listed in Table 1, which indicates that the GMZ01 bentonite has high cation exchange capacity and high adsorption ability.

\section{Experimental Methods}

The instantaneous profile method has been adopted in this study. This method was successfully used by many researchers to determine the unsaturated hydraulic conductivity of geomaterials (Daniel,

1982 ; Richards and Weeks, 1953; Hamilton et al., 1981; Watson, K.K., 1966; Meerdink et al., 1996;

Fujimaki and Inoue, 2003; Cui et al., 2008; Ye et al., 2010a). As an unsteady-state method, it can be used either in the laboratory or in situ (Benson and Gribb 1997).

In order to apply this method to determine the unsaturated permeability of the GMZ01 bentonite at different temperatures, on the one hand, the SWRCs of this soil should be determined at relevant temperatures, and on the other hand, the corresponding suction profiles should be determined by performing infiltration test at different temperatures with suction monitoring. For a given temperature, the hydraulic gradient was determined using the suction profile; the water flux was determined using the water content profile; the hydraulic conductivity was then calculated based on the generalized Darcy's law. The detailed calculation procedure can be found in Ye et al. (2009a).

\subsection{Determination of SWRCs 3.1.1 Suction control}

The vapour equilibrium technique (for high suctions) and osmotic technique (for low suctions) were employed for suction control in this study. At high suctions, the experimental setup used was described by Ye et al (2005), as shown in Fig.2. Note that the vapor equilibrium technique was employed by number of researchers for controlling total suction in unsaturated soil tests (Bernier et al, 1997; Blatz and Graham, 2000; Lloret et al, 2003; Chen et al, 2006).

In this study, the confined GMZ01 specimen was placed in a desiccator and the water vapour above a saturated salt solution was circulated to provide the desired suction to the specimen. Saturated salt solutions and their corresponding suctions imposed at 20,40 and $60^{\circ} \mathrm{C}$ are shown in Table 3 (Tang and Cui, 2005).

For low suctions, the osmotic technique was used and the corresponding setup is shown in Fig 3 (Delage et al., 1992; 1998). Note that Tang et al. (2010) studied the temperature effect on the calibration curve of PEG solutions and found that this effect is insignificant. Thus, in this study, the osmotic technique was employed without temperature correction.

\subsubsection{Apparatus}

Custom-designed stainless steel cells with small holes in two ends (Fig.2, Ye, 2009a) were employed for water retention test under confined conditions. The holes were designed as channels for 
moisture exchange between the specimen in the cell and the circulating air (or PEG solution) around it. For the temperature control, the setups were placed in ovens (Fig 3 and Fig 4), which have temperature controlled to an accuracy of $\pm 0.1^{\circ} \mathrm{C}$. Note that temperatures of 20,40 and $60^{\circ} \mathrm{C}$ were selected as the testing temperatures in this study.

\subsubsection{Specimen preparation}

The GMZ01 bentonite powder was compacted into a thin cylindrical specimen, which has a final dimension of $20 \mathrm{~mm}$ in diameter and $6 \mathrm{~mm}$ in height. For the compaction, a press was used and the compaction was carried out at a velocity of $0.1 \mathrm{~mm} / \mathrm{min}$. The final dry density and water content of the compacted specimen were $1.70 \mathrm{~g} / \mathrm{cm}^{3}$ and $10.65 \%$, respectively.

\subsection{Infiltration test}

The schematic layout of the temperature controlled infiltration test is shown in Fig.5. A custom-designed cylinder (Ye et al., 2009a, 2010a) is put in an oven with temperature controlled to an accuracy of $\pm 0.1^{\circ} \mathrm{C}$. The resistive relative humidity (RH) sensors (Cui et al, 2008) were used to monitor the RH changes. Note that the same type of sensor was used by Ye et al. (2009a, 2010a). It can be seen from Fig.5 that the sensors were installed every $30 \mathrm{~mm}$ along the length of the cell $(4$ sensors) with a fifth sensor in the upper base plate of the cell. As the sensors measure the air relative humidity, no direct contact with soil specimen was allowed. For this reason, a small cavity was bored in the soil for each transducer. This cavity had a dimension allowing introducing the transducer cap: a porous stone of $2 \mathrm{~mm}$ thick and $5 \mathrm{~mm}$ in diameter. This porous stone separated the transducer from the soil sample and allowed the air humidity transfer from the specimen to the transducer (Ye et al., 2009a).

The distilled water was used in the infiltration test. The water absorbed by the specimen can be quantified by calculating the water volume change in the left marked glass pipe, which can be compensated by water from the right tube, in the U-shaped system outside the oven. Two drops of silicone oil were added into the left pipe to prevent water evaporation. A soft tube was used for connecting the U-shaped system to the inlet of the specimen in order to warm up the water to current testing temperature before absorption. The humidity and temperature changes were recorded by the data logging system.

A double-piston mould was used for the compaction of the specimen (Cui and Delage, 1996). The powder of the GMZ01 bentonite was compacted in 5 layers. After the first layer $(30 \mathrm{~mm})$ was compacted and the surface of specimen was carefully scarified for the integrity of the specimen, the equal parts of the GMZ01 powder were added from two ends of the mould and then compacted to two $15 \mathrm{~mm}$ sub-layers. This procedure was repeated for the other 3 layers. The compaction was conducted at a speed of $0.1 \mathrm{~mm} / \mathrm{min}$. The specimen has a final height of $150 \mathrm{~mm}$, a dry density of $1.70 \mathrm{Mg} / \mathrm{m}^{3}$, a suction about $90 \mathrm{MPa}$ for $40^{\circ} \mathrm{C}$ temperature and $100 \mathrm{MPa}$ for $60^{\circ} \mathrm{C}$ temperature, and a degree of saturation around 0.49 for $40^{\circ} \mathrm{C}$ temperature and 0.41 for $60^{\circ} \mathrm{C}$ temperature.

The unsaturated permeability test on the GMZ01 bentonite at $20^{\circ} \mathrm{C}$ was previously measured and reported by Ye et al. (2010) and thus only the infiltration tests at temperatures of $40^{\circ} \mathrm{C}$ and $60^{\circ} \mathrm{C}$ were performed in this study.

\section{Results and discussion \\ 4.1 SWRCs}

The SWRCs of the highly-compacted GMZ01 specimen following wetting path at different 
temperatures $\left(20^{\circ} \mathrm{C}, 40^{\circ} \mathrm{C}\right.$ and $\left.60^{\circ} \mathrm{C}\right)$ under confined conditions are shown in Fig.5. Based on these results, an equation can be proposed to describe the water retention curves of the densely compacted GMZ01 bentonite $\left(1.7 \mathrm{Mg} / \mathrm{m}^{3}\right)$ :

$$
w=\eta \frac{w_{\text {sat }}}{\left\{\ln \left[2.72+(\psi / a)^{b}\right]\right\}^{c}}
$$

with

$$
\eta=1-\frac{\ln \left(1+\frac{\psi}{\psi_{r}}\right)}{1+\frac{1000}{\psi_{r}}},
$$

Where $\psi(\mathrm{MPa})$ is the suction; $\psi_{r}(\mathrm{MPa})$ is a reference suction (309 $\mathrm{MPa}$ in this study); $w_{\text {sat }}$ is the

water content in the saturated state: $w_{\text {sat }}=0.25+0.00018(T-20-273.4) ; \mathrm{T}(\mathrm{K})$ is the absolute

temperature; $a(\mathrm{MPa}), b$ and $c$ are soil parameters: $a=-4.1474 \operatorname{Ln}(T-273)+20.395 ; b=0.8086$;

$c=0.5864$.

Fig.6 indicates that, the water retention capacity decreases as temperature increases and the degree of the temperature influence depends on suction. This phenomenon can be analyzed separately at low and high suctions. At high suctions (> $4 \mathrm{MPa}$ ), changes of clay fabric and fluid in intra-aggregate spaces play a significant role in water retention capacity of GMZ bentonite. Intra-aggregate water moves into macro-pores (inter-aggregates pores) with temperature increase (Ye et al, 2009a). This process decreases the suction in the macro-pore level. As the suction is controlled, water flows out from the macro-pores, leading to a decrease of water retention capacity. At low suctions, capillary effect plays a decisive role in the water retention capacity. Increase of temperature causes changes in surface tension, which results in decrease of water content under constant suction conditions.

In order to quantitatively assess the influence of temperature on the water retention capacity of the bentonite under different suctions, a ratio $k_{\mathrm{T}}$ is defined as follows:

$$
k_{T}=\frac{w_{T 1}-w_{T 2}}{w_{T 1}} \times 100 \%
$$

where $w_{\mathrm{T} 1}$ and $w_{\mathrm{T} 2}$ are water content at temperature $T 1$ and $T 2$ respectively for the same suction.

The relationship between the ratio $k_{\mathrm{T}}$ and suction for the $\mathrm{GMZ} 01$ bentonite at $40^{\circ} \mathrm{C}$ and $60^{\circ} \mathrm{C}$ are given in Fig.7. It can be observed that the effect of temperature on the water retention capacity is closely related to suction, particularly in the range from 30 to $60 \mathrm{MPa}$. This effect reaches a maximum at a suction around $40 \mathrm{MPa}$.

\subsection{Unsaturated permeability}

\subsubsection{Test at $40^{\circ} \mathrm{C}$}

The relative humidity changes with hydration time in the infiltration test at $40^{\circ} \mathrm{C}$ are shown in Fig.8. Based on the SWRCs measured at $40^{\circ} \mathrm{C}$ (see Fig.6), the development of suction with hydration time can be obtained. Note that the conversion from relative humidity to suction was done using the 
Kelvin's law. Fig 8 indicates that, for the relative humidity sensor located $3 \mathrm{~cm}$ from the hydration water inlet at the bottom of the specimen, suction decreases rapidly in the first $200 \mathrm{~h}$ of hydration and then decreases much more slowly. For suction measured at $6 \mathrm{~cm}$, it begins to decrease rapidly after $100 \mathrm{~h}$ hydration and gradually decreases after $800 \mathrm{~h}$ hydration. As it is relatively far from the water inlet, suctions measured at $12 \mathrm{~cm}$ and $15 \mathrm{~cm}$ from the bottom of the specimen start to decrease rapidly after 200 and $300 \mathrm{~h}$ of hydration, respectively. The slope of the curve of suction versus time decreases as the distance from the inlet increases. The test was stopped after about $1670 \mathrm{~h}$ hydration, when the sensor at $3 \mathrm{~cm}$ distance from the inlet indicated that zero suction (100\% relative humidity) was achieved at this height.

The relationship between the unsaturated hydraulic conductivity and suction is shown in Fig.9. It can be observed that at $40^{\circ} \mathrm{C}$ temperature, the unsaturated hydraulic conductivity of the GMZ01 with a dry density of $1.7 \mathrm{Mg} / \mathrm{m}^{3}$ is on the whole between $1.64 \times 10^{-13} \mathrm{~m} / \mathrm{s}$ and $1.34 \times 10^{-14} \mathrm{~m} / \mathrm{s}$. During the initial stages of hydration, the hydraulic conductivity gradually decreases with suction decrease, and the hydraulic conductivity reaches the minimum value of $1.34 \times 10^{-14} \mathrm{~m} / \mathrm{s}$ when the suction drops to $45 \mathrm{MPa}$; the hydraulic hydraulic conductivity keeps steady in the range of suction from $20 \mathrm{MPa}$ to $60 \mathrm{MPa}$; but when suction drops to a level lower than $20 \mathrm{MPa}$, the unsaturated hydraulic conductivity increases rapidly and reaches $1 \times 10^{-13} \mathrm{~m} / \mathrm{s}$.

\subsubsection{Test at $60^{\circ} \mathrm{C}$}

The unsaturated hydraulic conductivity of the confined GMZ01 determined at $60^{\circ} \mathrm{C}$ is shown in Fig.10. It can be seen that the values are generally between $1.79 \times 10^{-14} \mathrm{~m} / \mathrm{s}$ and $1.19 \times 10^{-13} \mathrm{~m} / \mathrm{s}$. As the infiltration of water progresses, suction drops from $80 \mathrm{MPa}$ to $55 \mathrm{MPa}$, while the unsaturated hydraulic conductivity decreases slightly. With suction reduction from $55 \mathrm{MPa}$ to $20 \mathrm{MPa}$, the hydraulic conductivity remains almost constant despite of the suction changes. For suction lower than $20 \mathrm{MPa}$, the hydraulic conductivity rapidly increases with decreasing suction and reaches a final value of $1 \times 10^{-13} \mathrm{~m} / \mathrm{s}$.

When the soil suction is decreased from the initial value (about $80 \mathrm{MPa}$ ) to zero, the hydraulic conductivity first decreases from $2 \times 10^{-14} \mathrm{~m} / \mathrm{s}$ to $7 \times 10^{-15} \mathrm{~m} / \mathrm{s}$ and then increases to $1 \times 10^{-13} \mathrm{~m} / \mathrm{s}$, which is close to the saturated hydraulic conductivity. As in the first stage, water transfer is primarily governed by the network of large pores and these large pores are progressively decreasing in quantity and in size, resulting in hydraulic conductivity decreases. After completion of this large-pore clogging by gel creation, a normal conductivity increase with suction decrease is observed (Ye et al., 2009a).

\subsection{Influence of temperature on the unsaturated hydraulic conductivity}

To further assess the influence of temperature on the unsaturated permeability of the highly compacted GMZ01 bentonite, the unsaturated hydraulic conductivity of the confined specimen at $20^{\circ} \mathrm{C}$ (Ye et al, 2009a) are compared to those measured at $40^{\circ} \mathrm{C}$ and $60^{\circ} \mathrm{C}$ (Fig.11). It can be seen that under confined conditions, the unsaturated hydraulic conductivity of the highly compacted GMZ01 bentonite increases with temperature rise. Moreover, the rate of change also decreases as temperature increases. The temperature effect becomes more significant at higher suctions (above $20 \mathrm{MPa}$ ). In the range of lower suctions (less than $20 \mathrm{MPa}$ ), it is observed that the lower the suction the less the temperature effect. The possible explanation is that for lower suctions the moisture absorbed by the bentonite is mainly associated with microstructure changes and the temperature effect on the microstructure is not significant.

The influence of temperature on the hydraulic conductivity is mainly related to the influence of 
temperature on the water viscosity and the pore structure of the bentonite. To remove the influence of temperature on water viscosity, the relative hydraulic conductivity is introduced to allow for a better analysis of the influence of temperature on hydraulic conductivity. Relationships between the relative permeability and degree of saturation ( $\mathrm{Sr}$ ) of the confined GMZ01 at $40^{\circ} \mathrm{C}$ and $60^{\circ} \mathrm{C}$ are given in Fig.12. It can be observed that when $\mathrm{Sr}$ is higher than 0.57 , the hydraulic conductivity at $60^{\circ} \mathrm{C}$ is similar to that observed at $40^{\circ} \mathrm{C}$. This means that in this range of degree of saturation the influence of temperature on permeability is mainly due to the influence on water viscosity. On the contrary, when $\mathrm{Sr}$ is lower than 0.57 , the relative permeability at $40^{\circ} \mathrm{C}$ is found higher than that at $60^{\circ} \mathrm{C}$. Interestingly, this threshold corresponds to a suction of $60 \mathrm{MPa}$, and from Figs 9, 10 and 11 it can be observed that when s > $60 \mathrm{MPa}$ the hydraulic conductivity decreases with suction decrease. As mentioned above, in this suction range hydration leads to progressive macro-pores closing thus to a decrease in hydraulic conductivity. This macro-pore closing process can be assumed to be more significant at higher temperature because of softer clay aggregates and lower water viscosity, explaining a lower hydraulic conductivity at $60^{\circ} \mathrm{C}$ than at $40^{\circ} \mathrm{C}$. As the relative hydraulic conductivity has been found independent of temperature when $\mathrm{Sr}>0.57$ (Fig. 12), it can be supposed that the macro-closing process ended when $\mathrm{Sr}>0.57$; in other words, the influence of temperature on pore structure became insignificant in this range.

It is also important to note that the obtained results could be affected by the possible density gradient along the specimen as identified by Dixon et al. (2002) and Villar et al. (2008). This density gradient can be formed owing to the expansion of the hydrated bentonite that intrudes into the drier area under the effect of swelling pressure. If it occurs, the computation of degree of saturation without considering this gradient is not correct and the water retention curve considered is also inappropriate. In other words, the simultaneous profile method meets its limitation. Because in this study, no specific analyses were conducted after the infiltration tests, this phenomenon can not be verified. Further studies will be performed to investigate this aspect.

\section{Conclusions}

The SWRCs of the highly compacted GMZ01 confined specimens on wetting path and at different temperatures $\left(20^{\circ} \mathrm{C}, 40^{\circ} \mathrm{C}\right.$ and $\left.60^{\circ} \mathrm{C}\right)$ show that the water retention capacity decreases as temperature increases; and the influence of temperature depends on suction. The ratio $k_{\mathrm{T}}$ can be used to quantitatively describe the influence of temperature on water retention capacity of bentonite at different suctions.

Under confined conditions and at $40^{\circ} \mathrm{C}$ temperature, the unsaturated hydraulic conductivity of the GMZ01 bentonite at a dry density of $1.7 \mathrm{Mg} / \mathrm{m}^{3}$ is between $1.64 \times 10^{-13} \mathrm{~m} / \mathrm{s}$ and $1.34 \times 10^{-14} \mathrm{~m} / \mathrm{s}$. At $60^{\circ} \mathrm{C}$ temperature, the value is slightly lower, between $1.19 \times 10^{-13} \mathrm{~m} / \mathrm{s}$ and $1.79 \times 10^{-14} \mathrm{~m} / \mathrm{s}$.

For all the temperatures considered, the unsaturated hydraulic conductivity decreases slightly in the first stage of hydration. The value of the hydraulic conductivity becomes constant as hydration progresses. Finally, the hydraulic conductivity increases rapidly with suction decreases when saturation is approached. This phenomenon may be explained by the changes in the soil microstructure.

Under confined conditions, the hydraulic conductivity increases as temperature increases, at a rate that decreases with temperature rise. Also, the influence of temperature on the hydraulic conductivity is quite suction-dependant. At high suctions ( $>$ > $60 \mathrm{MPa}$ ) or low degrees of saturation 
( $\mathrm{Sr}<0.57)$, the temperature effect is mainly due to its influence on water viscosity; on the contrary, in the range of low suctions ( $<60 \mathrm{MPa}$ ) or high degrees of saturation $(\mathrm{Sr}>0.57)$, the temperature effect is related to both the water viscosity and the macro-pores closing phenomenon that is supposed to be temperature dependent. Note that further studies are needed to investigate the possible dry density gradient effect on the hydraulic conductivity determined based on the simultaneous profile method.

\section{ACKNOWLEDGEMENTS}

The authors are grateful to the National Natural Science Foundation of China (Projects No. 41030748, No.40772180 and No.40728003), Kwang-Hua Fund for College of Civil Engineering at Tongji University, China Atomic Energy Authority (Project [2007]831), and Shanghai municipality (Leading Academic Discipline Project - B308).

\section{References}

Benson C.H. and Gribb M.M. 1997. Measuring unsaturated hydraulic conductivity in the laboratory and field. In Unsaturated soil engineering practice. Edited by S.L. Houston and D.G. Fredlund. American Society of Civil Engineers (ASCE), Reston, Va. pp. 113-168.

Bernier F., Volckaert G., Alonso E.E. and Villar, M.V. 1997. Suction-controlled experiments on Boom clay. Engineering Geology, 47(4): 325-338

Blatz J. and Graham J. 2000. A system for controlled suction in triaxial tests. Geotechnique, 50(4): 465-469

Chen B., Qian L.X., Ye W.M., Cui Y.J. and Wang J. 2006. Soil-water characteristic curves of Gaomiaozi bentonite. Chinese Journal of Rock Mechanics and Engineering, Vo1.25(4): 788-793.

Cho W.J., Lee J.O. and K.S. Chun. 1999. The temperature effects on hydraulic conductivity of compacted bentonite. Applied Clay Science 14, 47-58.

Cho W.J., Lee J.O. and Kang C.H. 2000. Influence of temperature elevation on the sealing performance of the potential buffer material for a high-level radioactive waste repository. Annals of Nuclear Energy, Vol. 27: 1271-1284.

Cui Y. J. \& Delage P. 1996. Yielding and plastic behaviour of an unsaturated compacted silt. Géotechnique 46 (2): 291-311.

Cui Y. J., Tang A.M., Loiseau C, Delage P. 2008. Determining the unsaturated hydraulic conductivity of a compacted sand-bentonite mixture under constant-volume and free-swell conditions.Physics and Chemistry of the Earth, Vol. 33:462-471.

Daniel D.E. 1982. Measurement of hydraulic conductivity of unsaturated soils with thermocouple psychrometers. Soil Science Society of America Journal 20 (6), 1125-1129.

Delage P., Suraj de Silva G.P.R. and Vicol T. 1992. Suction controlled testing of non saturated soils with an osmotic consolidometer. Proceedings 7th International Conference on Expansive Soils, Dallas, 206-211.

Delage P., Howat M. and Cui Y.J. 1998. The relationship between suction and swelling properties in a heavily compacted unsaturated clay. Engineering Geology, vol.50 (1-2): 34-48.

Dixon D.A., Cheung S.C.H., Gray M.N. and Davidson B.C. 1987. The hydraulic conductivity of dense clay soils. Proceedings of the 40th Canadian Geotechnical Conference,Regina, Saskachewan - Canada:389-396. 
Dixon D., Chandler N., Graham J. and Gray M.N. 2002. Two large-scale sealing tests conducted at Atomic Energy of Canada's underground research laboratory: the buffer-container experiment and the isothermal test. Can. Geotech. J. 39: 503-518.

Fujimaki H. and Inoue M. 2003. A flux-controlled steady-state evaporation method for determining unsaturated hydraulic conductivity at low matric pressure head values. Soil Science, 168(6): 385-395.

Hamilton D.C., Gloeckler G., Krimigis S.M. and Lanzerotti L.J. 1981. Composition of nonthermal ions in the Jovian magnetosphere. Journal of Geophysical Research, 86(A10): 8301-8318.

He J. and Shi J. Y. 2007. Calculation of saturated hydraulic conductivity of bentonite. Chinese Journal of Rock Mechanics and Engineering, Suppl. 2: 3920-3925 (in Chinese).

Komine H. 2004. Simplified evaluation on hydraulic conductivities of sand-bentonite mixture backfill.Applied clay science, Vol.26 ( 1-4 ) :13-19.

Liu, Y.M. and Wen, Z.J. 2003. An investigation of the physical properties of clayey materials used in nuclear waste disposal at great depth.Mineral Rocks 23 (4), 42-45 in Chinese.

Lloret A., Villar M.V., Sanchez M., Gens A., Pintado X. and Alonso E.E. 2003. Mechanical behaviour of heavily compacted bentonite under high suction changes. Geotechnique, 53(1): $27-40$.

Loiseau C. 2001.Transferts d'eau et couplages hydromécaniques dans les barrières ouvragées. PhD Thesis. CERMES/ENPC, France.

Meerdink J.S., Benson C.H. and Khire M.V. 1996. Unsaturated hydraulic conductivity of two compacted barrier soils. Journal of Geotechnical Engineering, 122(7): 565-576.

Nachabe H.M. 1995. Estimating hydraulic conductivity for models of Soils with Macropores.Journal of Irrigation and Drainage Engineering, Vol.121 (1): 95-102.

Niu W.J., Ye W.M., Chen B. and Qian L.X. 2009. The Equations of Unsaturated Permeability Considering the Micro- structure. Exploration Engineering (Rock \& Soil Drilling and Tunneling), Vol. 36(6):34-39 (in Chinese).

Richards S.J. and Weeks L.V. 1953. Capillary conductivity values from moisture yield and tension measurements on soil columns. Soil Science Society of America Proceedings, 17: 206-209.

Sánchez M. 2004. Thermo-Hydro-Mechanical coupled analyses in low permeability media. PhD Thesis, Universitat Politècnica de Catalunya, Spain.

Tang A.M.,Cui Y.J. 2005. Controlling suction by the vapour equilibrium technique at different temperatures and its application in determining the water retention properties of MX80 clay Canadian Geotechnical Journal, Vol.42:1-10.

Tang A.M., Cui Y.J., Qian L.X., Delage P. and Ye W.M. 2010. Calibration of the osmotic technique of controlling suction with respect to temperature using a miniature tensiometer. Canadian Geotechnical Journal, Vol. 47(3/1): 359-365.

Towhata I., Kuntiwattanakul P., Seko I. and Ohishi K. 1993. Volume change of clays induced by heating as observed in consolidation tests. Soils Found. Vol. 33 (4), 170-183.

Villar M.V. 2000. Caracterización termo-hidro-mecánica de una bentonita de Cabo de Gata: Ph.D. Thesis. Universidad Complutense de Madrid. Madrid (in Spanish).

Villar M.V. 2002. Thermo-hydro-mechanical characterisation of a bentonite from Cabo de Gata. A study applied to the use of bentonite as sealing material in high level radioactive waste repositories.Publicación Técnica ENRESA, Madrid, Spain. 
Villar M.V. and Lloret A. 2004. Influence of temperature on the hydro-mechanical behaviour of a compacted bentonite . Applied Clay Science, Vol. 26(1/4): 337-350.

Villar M.V., Sánchez M., Gens A., 2008. Behaviour of a bentonite barrier in the laboratory: experimental results up to 8 years and numerical simulation. Physics and Chemistry of the Earth 33, S476-S485.

Watson K.K. 1966. An instantaneous profile method for determining the hydraulic conductivity of unsaturated porous materials. Water Resources Research, 2(4): 709-715.

Ye W.M., Cui Y.J., Qian L.X. and Chen, B. 2009a. An experimental study of the water transfer through confined compacted GMZ bentonite, Engineering Geology, v 108, n 3-4, p 169-176

Ye W.M., Niu W.J., Chen B., Chen Y.G. 2010a. Unsaturated Hydraulic Conductivity of Densely Compacted Gaomiaozi Bentonite Under Unconfined Conditions, Journal of Tongji University (Natural Science), Vol 38(10): 1439-1443, in Chinese.

Ye W.M., Wan M., Chen B., Chen Y. G., Cui Y. J. and Wang J. 2009b. Effect of temperature on soil-water characteristics and hysteresis of compacted Gaomiaozi bentonite. Journal of Central South University of Technology. Vol.16, No.5: 821-826.

Ye W.M., Tang Y.Q. and Cui Y.J. 2005. Measurement of soil suction in laboratory and soil-water characteristics of Shanghai soft soil. Chinese Jounal of Geotechnical Engineering, 27(3):347-349 (in Chinese).

Ye W.M., Chen Y.G., Chen B., Wang Q. and Wang J. 2010b. Advances on the knowledge of the buffer/backfill properties of heavily compacted GMZ bentonite. Engineering Geology, Vol 116(1-2): 12-20. 
390

391

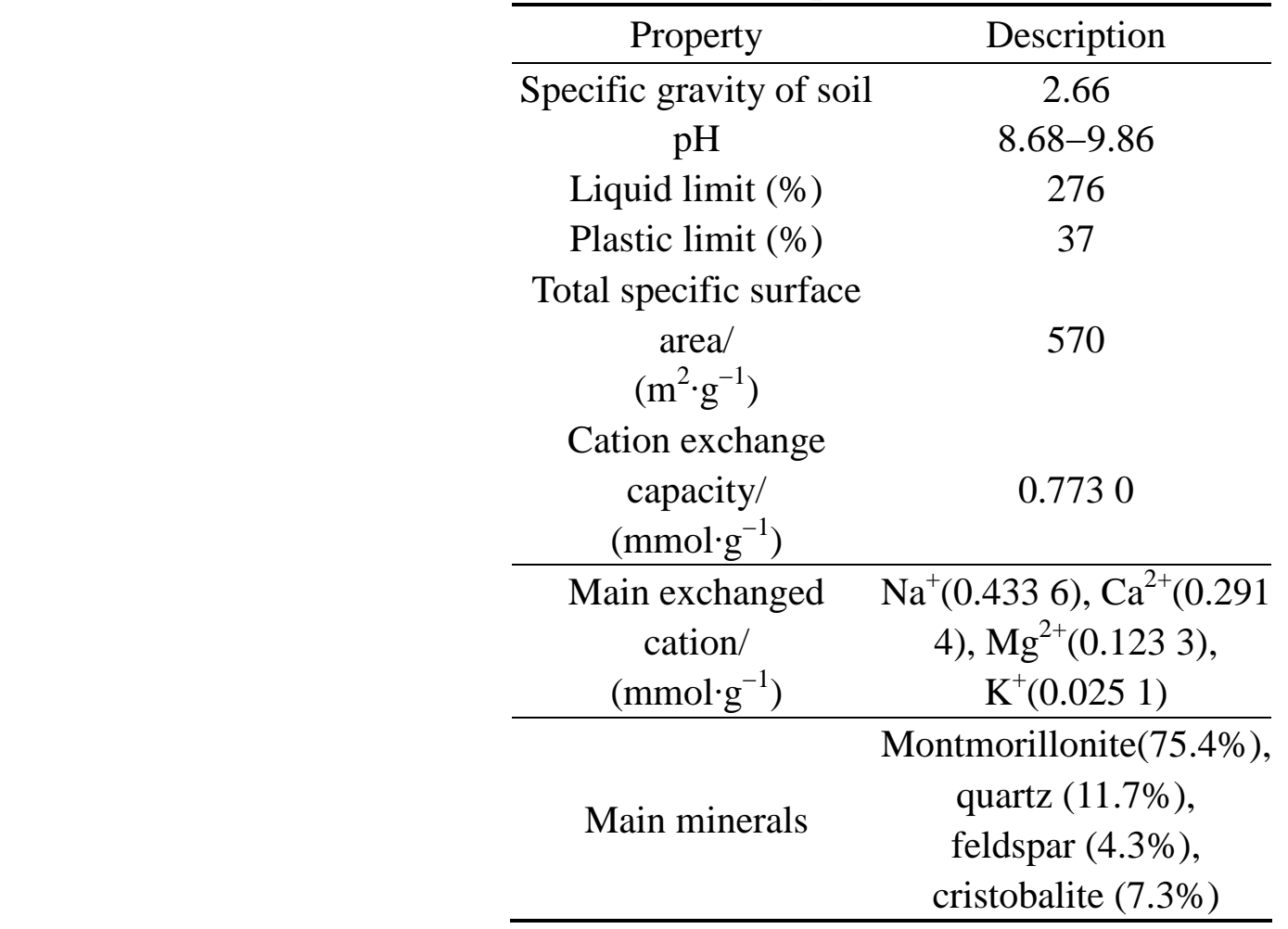

392

393

394

Table 2 Salt solution and corresponding suction at different temperatures (MPa)(Tang 2005)

\begin{tabular}{cccc}
\hline Salt solution & $20^{\circ} \mathrm{C}$ & $40^{\circ} \mathrm{C}$ & $60^{\circ} \mathrm{C}$ \\
\hline $\mathrm{LiCl}_{2}$ & 309.0 & - & 340 \\
$\mathrm{MgCl}_{2}$ & 150.0 & 162.4 & 187.7 \\
$\mathrm{~K}_{2} \mathrm{CO}_{3}$ & 113.0 & 122.0 & 144.8 \\
$\mathrm{Mg}\left(\mathrm{NO}_{3}\right)_{2}$ & 82.0 & 103.1 & 139 \\
$\mathrm{NaNO}_{2}$ & 57.0 & - & \\
$\mathrm{NaNO}_{3}$ & 39.0 & 49.5 & 61.6 \\
$\mathrm{NaCl}$ & 38.0 & 40.6 & 44.2 \\
$\left(\mathrm{NH}_{4}\right)_{2} \mathrm{SO}_{4}$ & 24.9 & 32.2 & \\
$\mathrm{KCl}$ & 21.0 & 27.8 & 33.4 \\
$\mathrm{ZnSO}_{4}$ & 12.6 & - & \\
$\mathrm{KNO}_{3}$ & 9.0 & - & \\
$\mathrm{K}_{2} \mathrm{SO}_{4}$ & 4.2 & 5.1 & 5.5 \\
\hline
\end{tabular}




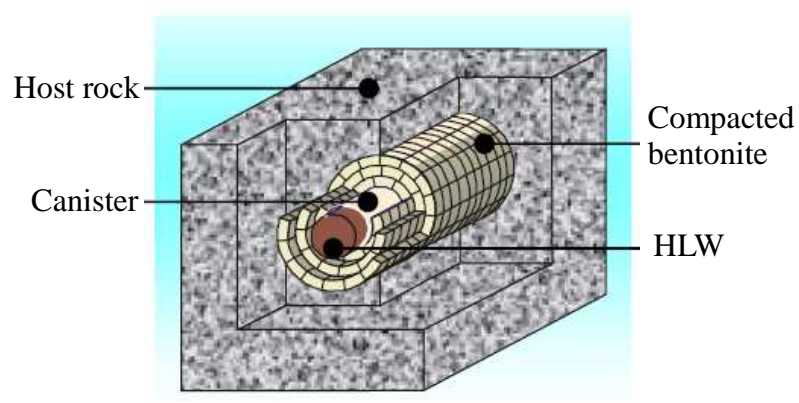

Fig. 1. Schematic view of a high level nuclear waste repository (Sanchez, 2004)

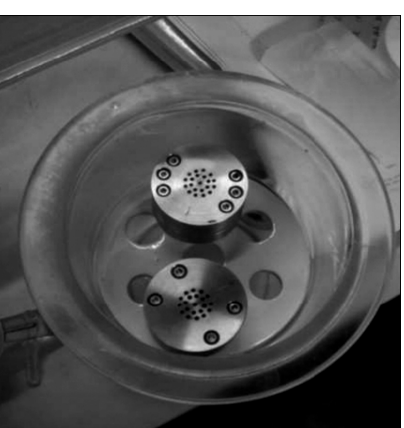

Fig. 2. Constant-volume hydration cell

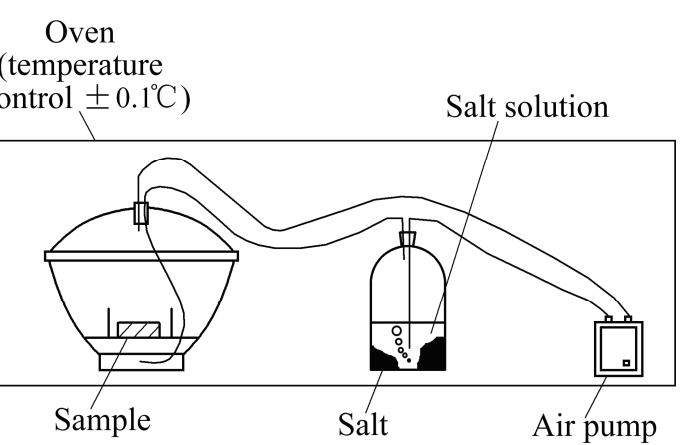

Fig. 3. Setup for the water retention curve determination using the vapor equilibrium technique

Oven(temperature Control ; $\grave{\mathrm{A}} 1^{\circ} \mathrm{C}$ )

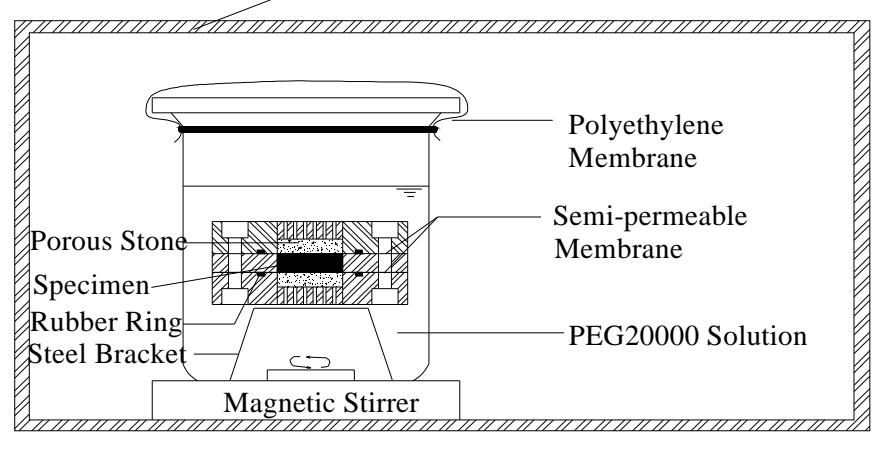

Fig. 4. Setup for the water retention curve determination using the osmotic technique 


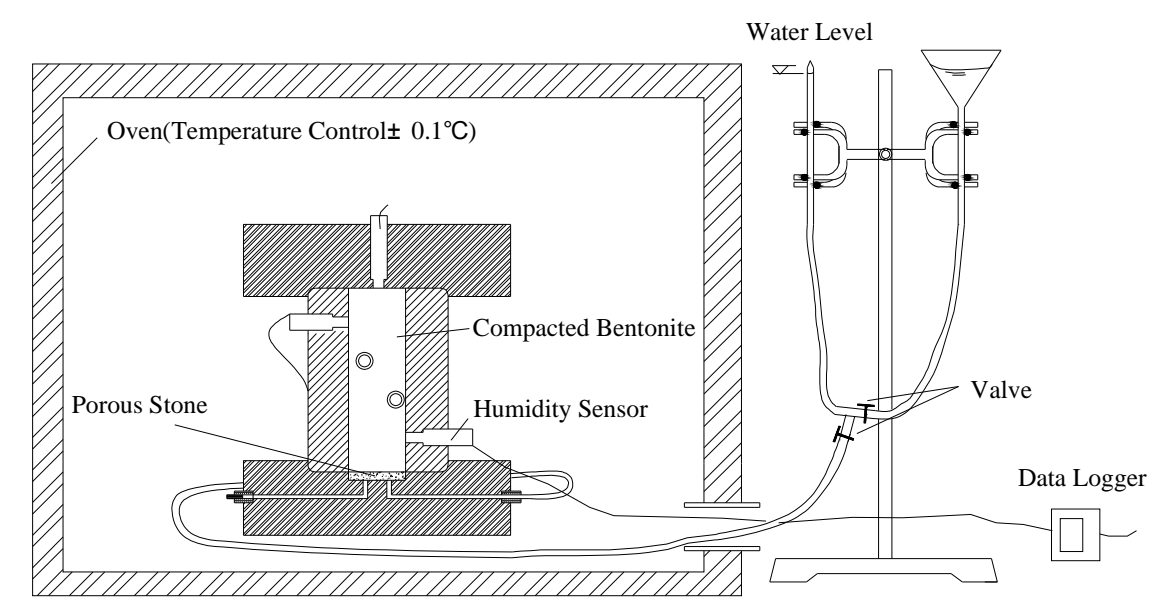

Fig. 5. Schematic layout of the temperature controlled infiltration test

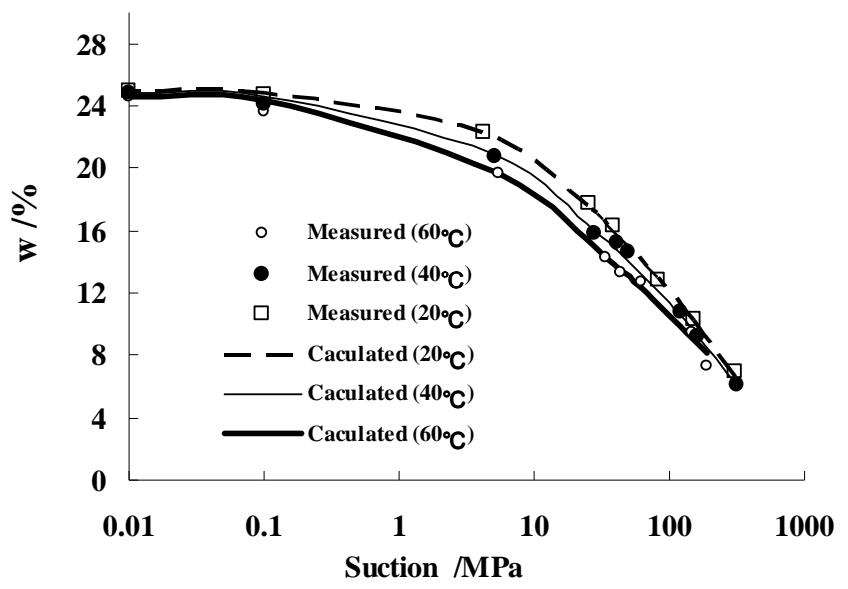

Fig. 6. Water retention curves of the confined specimen at different temperatures

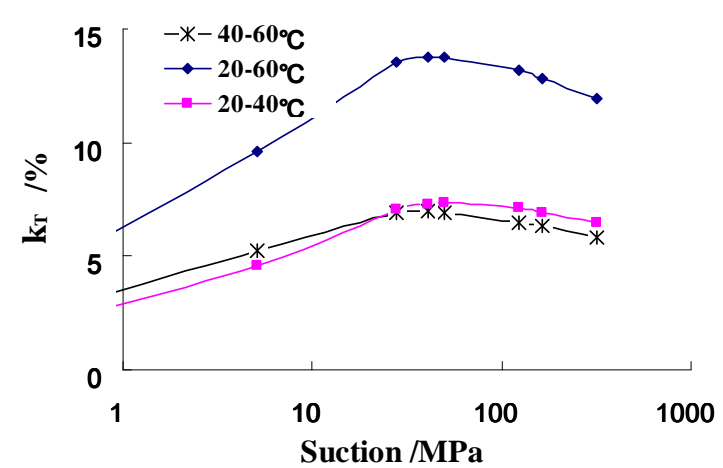

Fig. 7. Change of $K_{T}$ with suction 
417

418

419

420

421

422

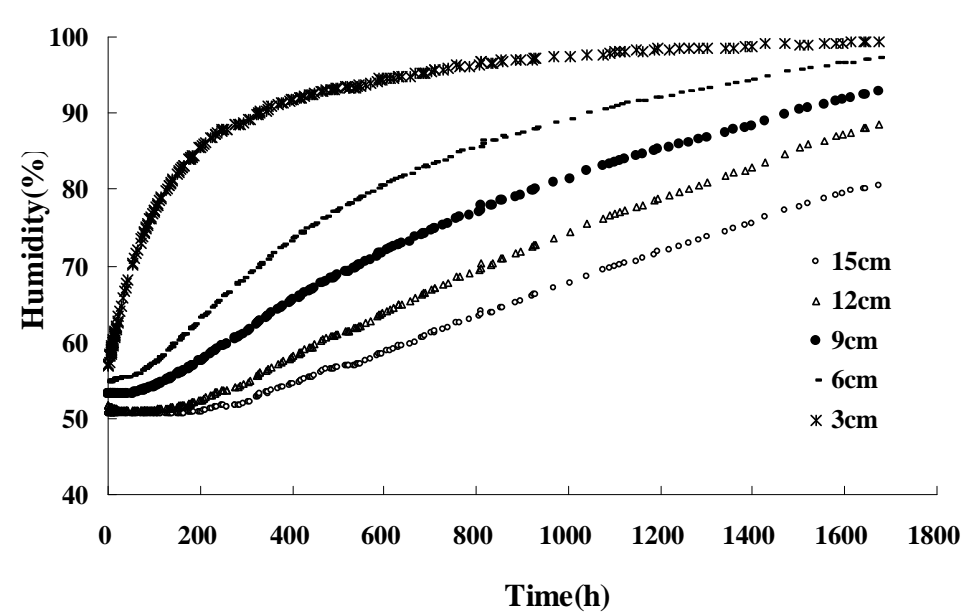

Fig. 8. Evolution of the relative humidity of confined GMZ01 with time at $40^{\circ} \mathrm{C}$

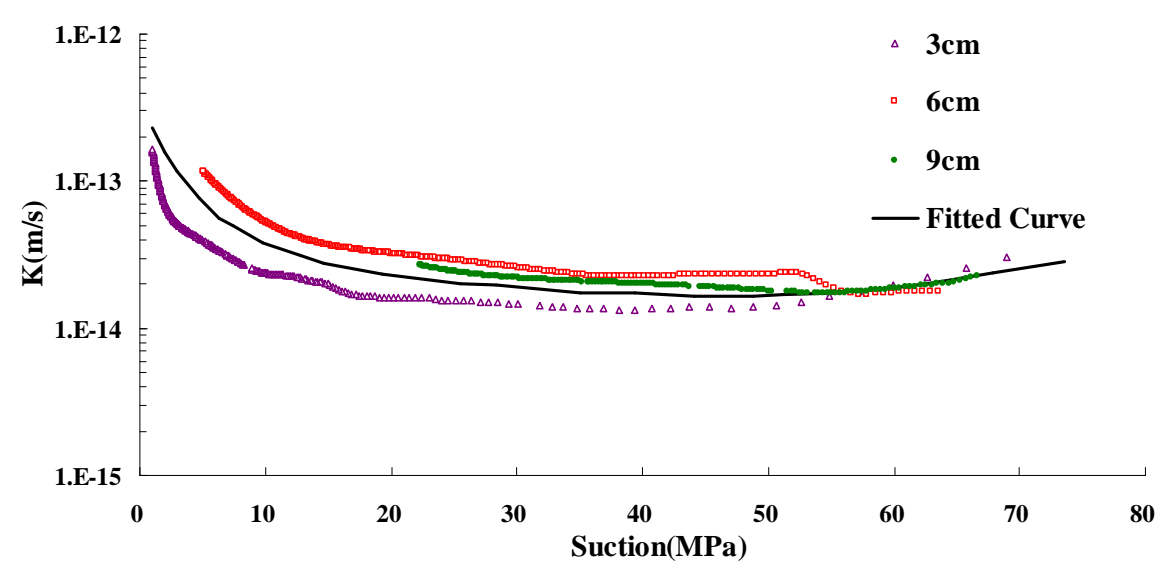

Fig. 9. Change of unsaturated hydraulic conductivity with suction for the confined GMZ01 at $40^{\circ} \mathrm{C}$

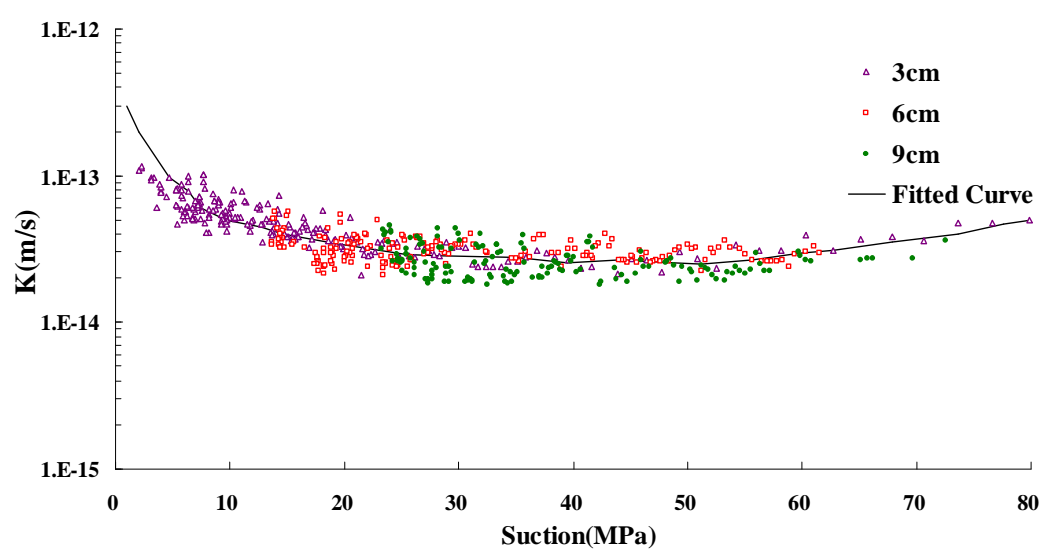

Fig. 10. Change of unsaturated hydraulic conductivity with suction for the confined GMZ01 at $60^{\circ} \mathrm{C}$ 


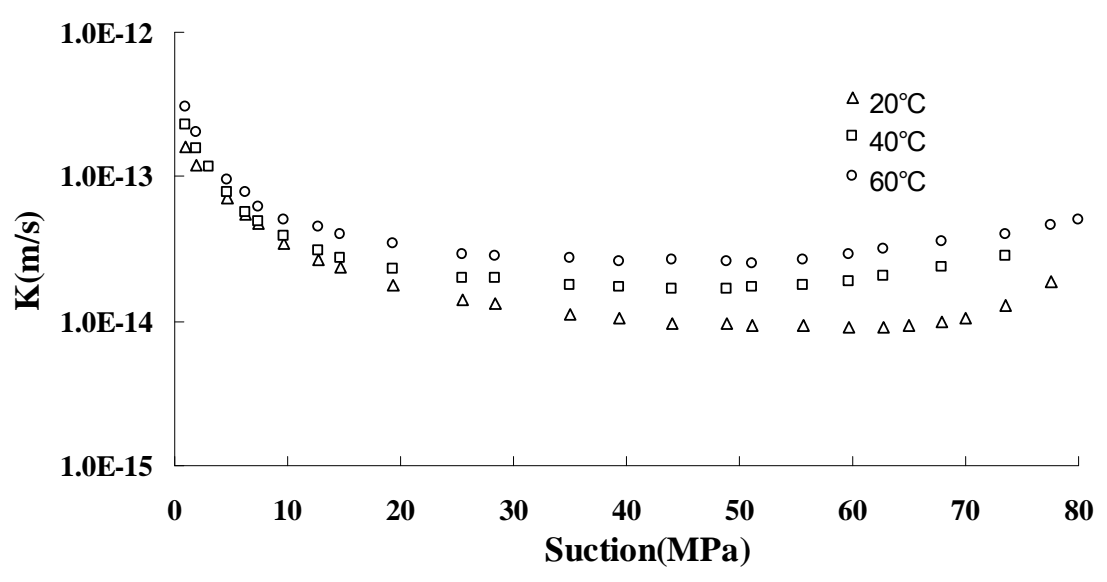

423
424

425

426

427

428

429
Fig. 11. Evolution of unsaturated hydraulic conductivity with suction for the confined GMZ01 at different temperatures

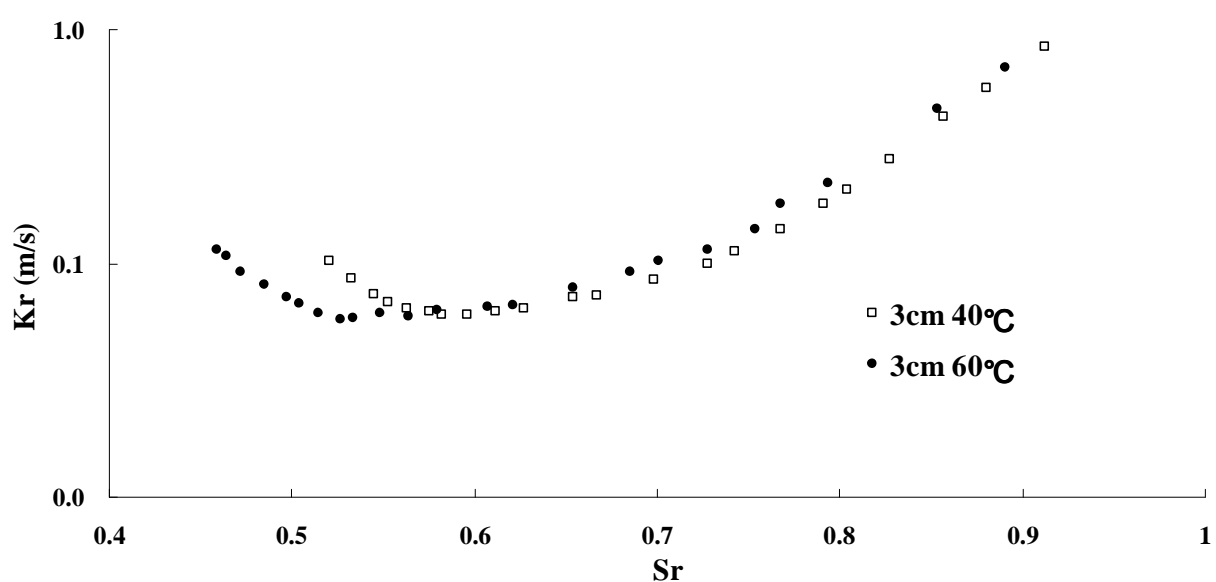

Fig. 12. Relationship between $\mathrm{Kr}$ and $\mathrm{Sr}$ of the confined $\mathrm{GMZ} 01$ at $40^{\circ} \mathrm{C}$ and $60^{\circ} \mathrm{C}$ 